Araştırma Makalesi / Research Article

\title{
Açık Ocak Albit İşletmesindeki Kaya Şevlerinin Sonlu Elemanlar Yöntemi Kullanılarak Duraylıık Değerlendirmesi
}

Slope Stability Assessment of Rock Slopes in an Open Pit Albite Mine Using Finite Element Method (FEM)

\section{Tümay KADAKÇI KOCA, M. Yalçın KOCA}

Dokuz Eylül Üniversitesi, Mühendislik Fakültesi, Jeoloji Mühendisliği Bölümü, Buca, IZMIR.

$\begin{array}{lll}\text { Geliş (received) } & : & \text { 01 Kasım (November) } 2013 \\ \text { Düzeltme (revised) } & : & \text { 09 Ocak (January) } 2014 \\ \text { Kabul (accepted) } & : & 13 \text { Ocak (January) } 2014\end{array}$

ÖZ

Çalışma alanı, Aydın, Çine-Karpuzlu' da bulunan Alipaşa açık ocak albit madenidir. Maden sahasında sadece lökokratik ortognayslar yüzlek vermektedir. Albit cevheri, K65B yönünde $129 \mathrm{~m}$ genişliğe, K25D yönünde yaklaşık 900 m uzunluğa sahiptir. Alipaşa albit açık ocak işletmesinin bugünkü taban kotu $395 \mathrm{~m}$ iken, tabandan itibaren $45 \mathrm{~m}$ daha işletilmesi planlanmaktadır. Bu çalışmanın amacı, ocağın doğu şevleri için, maden çıkarma çalışmaları bittikten sonraki optimum şev açısının belirlenmesidir. Bu kapsamda, kaya kütlesinin ayrıntılı arazi gözlemleri yapılmış ve kaya materyali üzerinde laboratuvar deneyleri gerçekleştirilmiştir. Daha, sonra bu veriler ile açık ocaktaki derin şevler için ( $\mathrm{H}>100 \mathrm{~m})$ nümerik analiz çalışmaları yürütülmüştür. Yapılan nümerik analizlerde, sonlu elemanlar yöntemi (FEM) kullanılarak, Genelleştirilmiş Hoek-Brown Ölçütü’nün ve eşdeğer Mohr-Coulomb parametrelerinin çalışma alanındaki çatlaklı kaya şevine uygulanabilirliği incelenmiştir. Analizler kapsamında, arazideki yerel blok kaymalarından etkilenen alandan geçen, tansiyon çatlaklarına dik beş adet jeoteknik kesit alınmış, farklı Jeolojik Dayanım İndeksi (GSI), sismik ivme katsayısı, şev açısı ve yeraltısu durumu değerleri kullanılarak, iki boyutlu sonlu eleman analizi yapabilen Phase2 V.7.013 programı yardımı ile duraylı1ık analizleri yapılmıştır. Analizler sonucunda, her bir kesit için güvenlik katsayısı değerleri (gerilme azaltma faktörleri - SRF) elde edilmiş, şevin yenilme mekanizması ortaya çıkarılmış ve şevin yenilme türünün nedenleri araştırılmıştır. Her iki yöntemden (Genelleştirilmiş Hoek-Brown ve Eşdeğer Mohr-Coulomb Ölçütü) elde edilen gerilme azaltma faktörü (SRF) değerleri, SPSS V.15.0.1 programı kullanılarak karşılaştırılmış ve çalışma alanındaki ortognaysları en iyi temsil eden ölçüt doğrultusunda, nihai şev açısı belirlenmiştir. 
Kadakçı Koca, Koca

Anahtar Kelimeler: Albit açık ocak işletmesi, Eşdeğer Mohr-Coulomb parametreleri, Genelleştirilmiş Hoek-Brown Ölçütü, Ortognays, Sonlu Elemanlar Yöntemi (FEM), Şev duraylılı̆̆ı.

\section{ABSTRACT}

The study area is Alipaşa open pit albite mine which takes place in Aydin, Çine-Karpuzlu. Only leucocratic orthogneiss rock unit outcrops out in the mine. The albite mineralisation located in the N25E direction with $900 \mathrm{~m}$ length and in the $\mathrm{N65} \mathrm{W}$ direction with $120 \mathrm{~m}$ width. $45 \mathrm{~m}$ thickness below the present mine base $(395 \mathrm{~m})$ of the open pit has been planned to be mined. The scope of this study is to determine the optimum overall slope angle of the eastern slopes of the mine at the time which the mining operations are terminated. In this context, based on the detailed field investigation and laboratory tests performed on the rock material, numerical analyses for the deep slopes $(H>100 \mathrm{~m})$ were conducted. In the numerical modelling, applicability of the finite element method (FEM) considering the Generalized Hoek-Brown Criterion and Equivalent Mohr-Coulomb parameters to the jointed rock slopes in the study area was investigated. In this process, firstly five geotechnical cross-sections passing through the area affected from local rock block slides were taken; secondly stability analyses of the overall slopes along these crosssections considering the variations of Geological Strength Index (GSI), seismic acceleration coefficient, slope angle and water table location (WTL) were conducted by using a two-dimensional FEM software Phase2 V.7.013. The causes and mechanisms of the slope instabilities, the factor of safety values (stress reduction factors: SRF) for each cross-section were determined. The results obtained from each criterion were compared by statistical software SPSS V.15.0.1 to determine the optimum overall slope angle in terms of the best fitting criterion for the orthogneisses.

Key Words: Albite open pit mine, Equivalent Mohr-Coulomb parameters, Generalized Hoek-Brown Criterion, Orthogneiss, Finite Element Method (FEM), Slope stability.

\section{GİRİs}

Şev duraylılığ , gerek maden işletmelerinde gerekse karayolları şevlerinde ayrıntılı olarak çalışılması gereken önemli konulardandır. Yetersizjeolojik çalışmalar sonucu gelişen değişik kütle hareketleri, maden çıkarma sürecinde maddi zararlara ve hatta can kayılarına neden olabilmektedir. Şev duraylılığı, yerel jeolojik koşullar, sismik aktivite, yeraltı su tablası ve boşluk suyu basıncındaki değişimler gibi birçok etken tarafindan denetlenir. Bu çalışmada, maden çıkarma işlemi bittikten sonraki şev geometrisi için, nihai şev açısı belirlenmiştir. Şev duraylılığı incelemeleri nümerik modeller üzerinden Hoek vd. (2002) ve Hoek (2006) tarafindan önerilen sırasıyla Genelleştirilmiş Hoek-Brown Ölçütü ve Eşdeğer Mohr-Coulomb parametreleri kullanılarak yürütülmüştür. 
Daha önceden yapılan dinamik koşullardaki şev duraylılık analizi çalışmalarında (Sofianos ve Halakatevakis, 2002; Sofianos, 2003; Sofianos ve Nomikos, 2006; Li vd., 2008; Nekouei ve Ahangari, 2013) sonlu elemanlar yönteminde Genelleştirilmiş Hoek-Brown Ölçütü ve Eşdeğer Mohr-Coulomb parametreleri karşılaştırmalı olarak uygulanmamıştır. Sofianos ve Halakatevakis (2002), GSI değeri 25'ten büyük kaya kütlelerinde açılan tüneller için Eşdeğer Mohr-Coulomb parametrelerini tahmin eden eşitlikler önermişlerdir. Sofianos (2003) ise, Eşdeğer Mohr-Coulomb parametrelerini tahmin ederken, gerilme aralığının alt limitini, kayanın iki eksenli çekme dayanımı olarak değiştirerek, destekli tüneller için destek basıncını da dikkate alan eşitlikler önermiştir. $\mathrm{Bu}$ eşitliklerden elde edilen c ve $\phi$ 'yi, Hoek vd. (2002), Hoek ve Brown (1997) ile belirlenen kohezyon (c) ve içsel sürtünme açısı $(\phi)$ değerleri ile karşılaştırarak, önerilen yeni eşitliğin kullanışı olduğunu belirtmiştir. Sofianos ve Nomikos (2006) ise, kırılgan ve plastik kayalarda açılan destekli tüneller için, Sofianos (2003)'ün önerdiği eşitliği uygulamışlar, iki yöntemin birbirine tek bir durum için uyarlanamayacağını ve her çalışma için farklı eşitliklerin kullanılması gerektiğini belirtmişlerdir. Li vd. (2008), kaya şev duraylılığg tablosu oluştururken, Eşdeğer Mohr-Coulomb parametreleri ve Hoek-Brown Ölçütü'nü karşılaştırmalı olarak, limit-denge analiz yöntemi aracılığıyla kullanmıştır. Aynı çalışmada, $45^{\circ}$ den daha eğimli yamaçlar için, Eşdeğer Mohr-Coulomb parametreleri kullanılarak oluşturulan duraylılık tablolarından elde edilen güvenlik katsayısının yüksek olduğu, buna, iki yöntemin eğrilerinin geometrik olarak en çok farklılık gösterdiği gerilme aralığının neden olduğu, Hoek-Brown Ölçütü ve MohrCoulomb eğrilerinin tek bir yaklaşımla birbirine uydurulamayacağı belirtilmiş, $45^{\circ}$ den büyük eşit ve küçük eğime sahip şevler için en küçük asal gerilmeyi hesaplayan iki farklı eşitlik önerilmiştir. Bu yolla, her iki yöntem için yakın sonuçlar elde edilmiştir. Nekouei ve Ahangari (2013) ise, Li vd. (2008) tarafından oluşturulan şev duraylılık tablolarında, Hoek-Brown Ölçütü ve Eşdeğer Mohr-Coulomb parametrelerine ait değerlerin düşük korelasyona sahip olduğunu, Hoek-Brown Ölçütü'nün güvenilir ve doğru olmayacağını belirtmişlerdir.

Alipaşa açık ocak albit madeni, Menderes Masifi'nde işletilen madenlerden biridir ve Menderes Masifi'nin çekirdek serilerinin tipik litolojisine uygun olarak şist anklavları içeren ortognaysların içerisinde yer almaktadır. Geçmiş yıllarda açık işletmenin doğu şevlerinde duraysızlıklar meydana gelmiştir. $\mathrm{Bu}$ duraysızlıklar şev basamaklarında gerçekleşmiş, arazide gözlenen tansiyon çatlakları bu hareketlerin işaretleri olarak şev üst yüzeylerinde ve şev basamaklarında gelişmiştir. Bir ve/ veya birden fazla şev basamağında, foliasyon düzlemlerinin basamak şevlerini kesmesine bağlı olarak düzlemsel kaymaların tüm şevi etkileyip etkilemeyeceği, etkilemesi durumunda nihai şev açısının ne olacağı önem kazanmaktadır. Tanyaş ve Ulusay (2013), Alipaşa açık ocağının doğu ve batı şevlerini, düzlemsel ve kama tipi yenilme açısından, kinematik olarak ve psödo-statik limit denge analiz yöntemiyle geri analizler yaparak incelemiştir. Yapılan analizler sonucunda, $35^{\circ}$ 'lik nihai şev açısı için, şev basamaklarında düzlemsel ve kama tipi yenilmeye ait veriler elde 
etmişler, ancak tüm şevde herhangi bir yenilme gözlenmeyeceği sonucuna varmışlardır.

Çalışma alanı ve çevresi için, meteorolojik veriler gözönüne alındığında, en çok yağışın kış ve bahar aylarında düştüğü ve aylık ortalama yağışın $110.4 \mathrm{~mm}$ olduğu belirlenmiştir. $\mathrm{Bu}$ doğrultuda, arazi çalışmaları yağışların şiddetlendiği ocak ayında yapılmış ve şevin \% 50 oranında bir doygunluğa eriştiği gözlenmiştir.

\section{INCELEME ALANININ JEOLOJISI}

Çalışma alanı, Menderes Masifi'nin güney kesiminde, Çine Asmasifi olarak adlandırılan bölgede yer almaktadır (Şekil 1). Asmasif, iri taneli gözlü gnays ve ince taneli mikaca zengin gnayslar tarafindan temsil edilmektedir. Ortognayslar kısmen foliasyonlu-çatlaklı kaya birimleri olup, açık işletmede ve civarında foliasyonların eğim açıları $30^{\circ}$ ile $42^{\circ}$ arasında değişmektedir (Şekil 1).

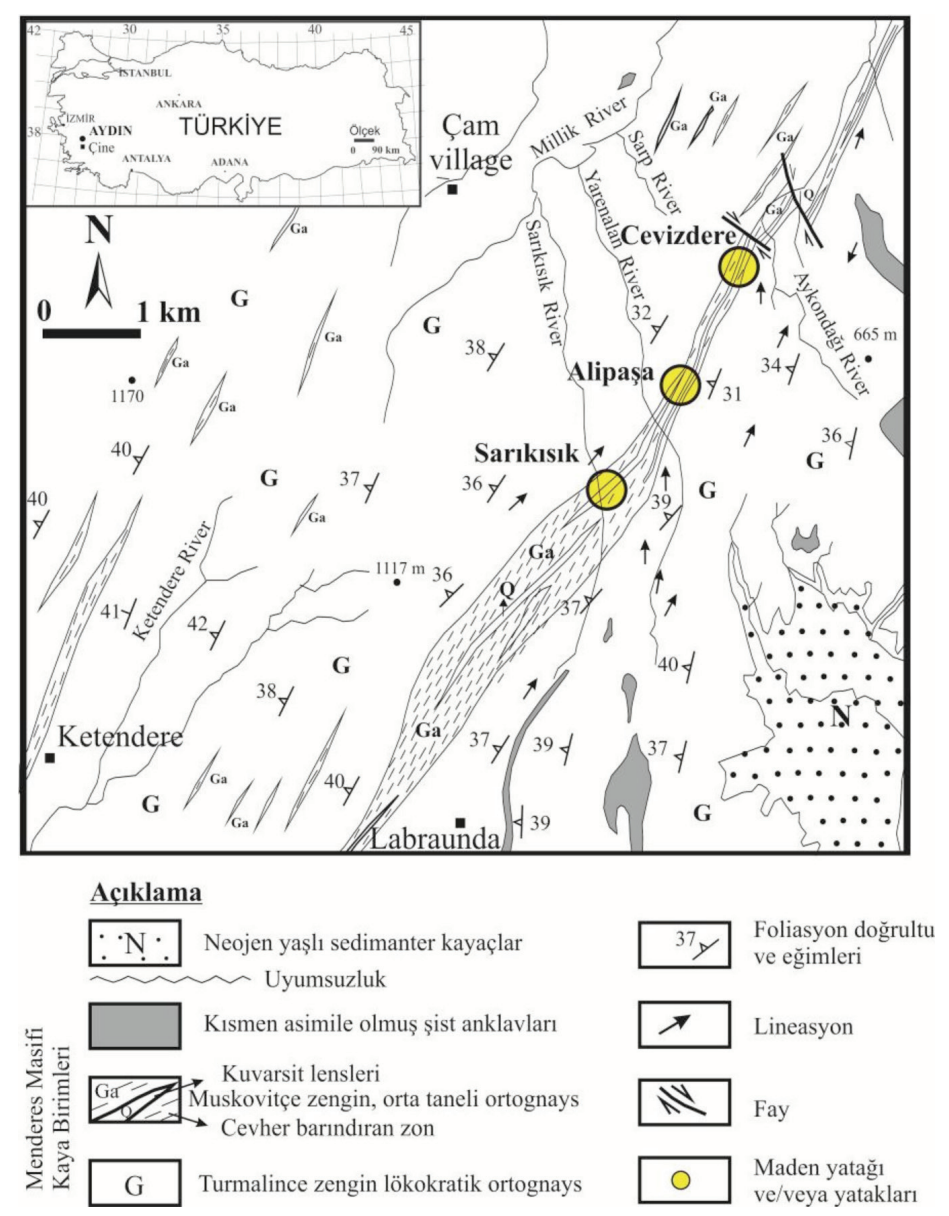

Şekil 1. Çalışma alanının lokasyon ve jeoloji haritası (Graciansky, 1965'ten değiştirilerek alınmıştır).

Figure 1. Location and geological map of the study area (modified from Graciansky, 1965). 
Ege Bölgesi'ni etkileyen KKD-GGB doğrultusundaki genişleme tektoniğine bağlı olarak gelişen KD-GB uzantılı makaslama zonları, yaygın jeolojik yapılar olarak Menderes Masifi'nde gözlenmektedir (Şengör, 1987; Candan vd., 2005). Çalışma alanında bulunan jeolojik birimler, bu tektoniğe bağlı olarak gelişmiş K25D doğrultusundaki makaslamanın etkisiyle deformasyona uğramışlardır. Sonuçta, foliasyon düzlemlerine dik makaslama eklemleri oluşmuştur. Na-feldispat içeren cevherleşme de (albit) bu makaslama zonları boyunca gelişmiştir (Graciansky, 1965; Uygun ve Gümüşçü, 2000).

\section{DEPREMSELLIKK}

Deprem etkisiyle oluşan şev yenilmeleri sık karşılaşılan bir durumdur ve çalışma alanını kapsayan Aydın yöresi de birinci derece deprem bölgesinde yer almaktadır. Buna bağlı olarak, şev duraylılık analizleri, sismik etki dikkate alınarak yürütülmüştür.
Büyük Menderes Fay Zonu'nda 1899 y1lında 6.9 büyüklüğünde oluşan deprem 1100 kişinin ölümüne neden olmuştur (http://earthquake.usgs. gov/earthquakes/world/historical.php/). Nümerik analizlerde kullanılan sismik katsayı değerleri $\left(\alpha_{\text {sismik }}\right)$, oluşabilecek deprem büyüklükleri ve fay zonunun çalışma alanına uzaklığı $(26.5 \mathrm{~km})$ dikkate alınarak, Fukushima ve Tanaka (1990) tarafından önerilen ampirik azalım eşitliği ile hesaplanmıştır (Tablo 1) .

$\log _{10} \mathrm{a}=0.42 \mathrm{M}_{\mathrm{w}}-\log \left(\mathrm{R}+0.025 * 10^{0.42 \mathrm{M}}\right)-$ $0.0033 \mathrm{R}+1.22$

$\alpha_{\text {sismik }}=\mathrm{a} / \mathrm{g}$

a: Yatay maksimum yer ivmesinin ortalama değeri $\left(\mathrm{cm} / \mathrm{sn}^{2}\right)$

$\mathrm{M}_{\mathrm{w}}$ : Moment büyüklüğü

R: Fay kırı̆ğ ile incelenen alan arasındaki en kısa mesafe $(\mathrm{km})$

$\alpha_{\text {sismik }}:$ Sismik katsay1

$\mathrm{g}$ : Yerçekimi ivmesi (gal)

Çizelge 1.Farklı deprem moment büyüklükleri için, Fukushima ve Tanaka (1990) tarafından önerilen ampirik azalım eşitliği ile hesaplanan sismik katsayı değerleri.

Table 1. The seismic acceleration values calculated from the empirical attenuation equation proposed by Fukushima and Tanaka (1990) for various earthquake moment magnitudes.

\begin{tabular}{llllll}
\hline Tanım & \multicolumn{5}{c}{ Değerler } \\
\hline $\mathrm{M}_{\mathrm{w}}$ & 5.5 & 5.8 & 6.0 & 6.5 & 7.0 \\
$\mathrm{R}(\mathrm{km})$ & 26.5 & 26.5 & 26.5 & 26.5 & 26.5 \\
$\mathrm{a}\left(\mathrm{cm} / \mathrm{sec}^{2}\right)$ & 103 & 112 & 130 & 182 & 245 \\
$\boldsymbol{\alpha}_{\text {sismik }}(\mathrm{g})$ & 0.10 & 0.11 & 0.13 & 0.18 & 0.25 \\
\hline
\end{tabular}


Kadakçı Koca, Koca

\section{INCELEME ALANININ MÜHENDISLLIK JEOLOJISİ}

Bir kaya şevinin tasarımı için kaya kütlesi içerisindeki süreksizliklerin içsel sürtünme açısı ve kohezyon değerinin bilinmesi gerekmektedir. Çünkü duraylılık, süreksizliklerin konumuna ve bazı jeomekanik ve jeoteknik özelliklerine bağlıdır (Hoek ve Bray, 1981). Özellikle, kayması muhtemel bloğun ağırlı̆̆ından kaynaklanan, kayma yönündeki bileşeninin büyüklüğü, şev duraylılı̆̆ında önemli rol oynamaktadır. Çalışma alanında, tektonik kökenli eklemler, metamorfizmaya bağlı olarak gelişmiş foliasyon düzlemleri ve çekme gerilmelerine bağlı olarak oluşan tansiyon çatlakları olmak üzere üç farklı süreksizlik tipi gözlenmiştir (Şekil 2).

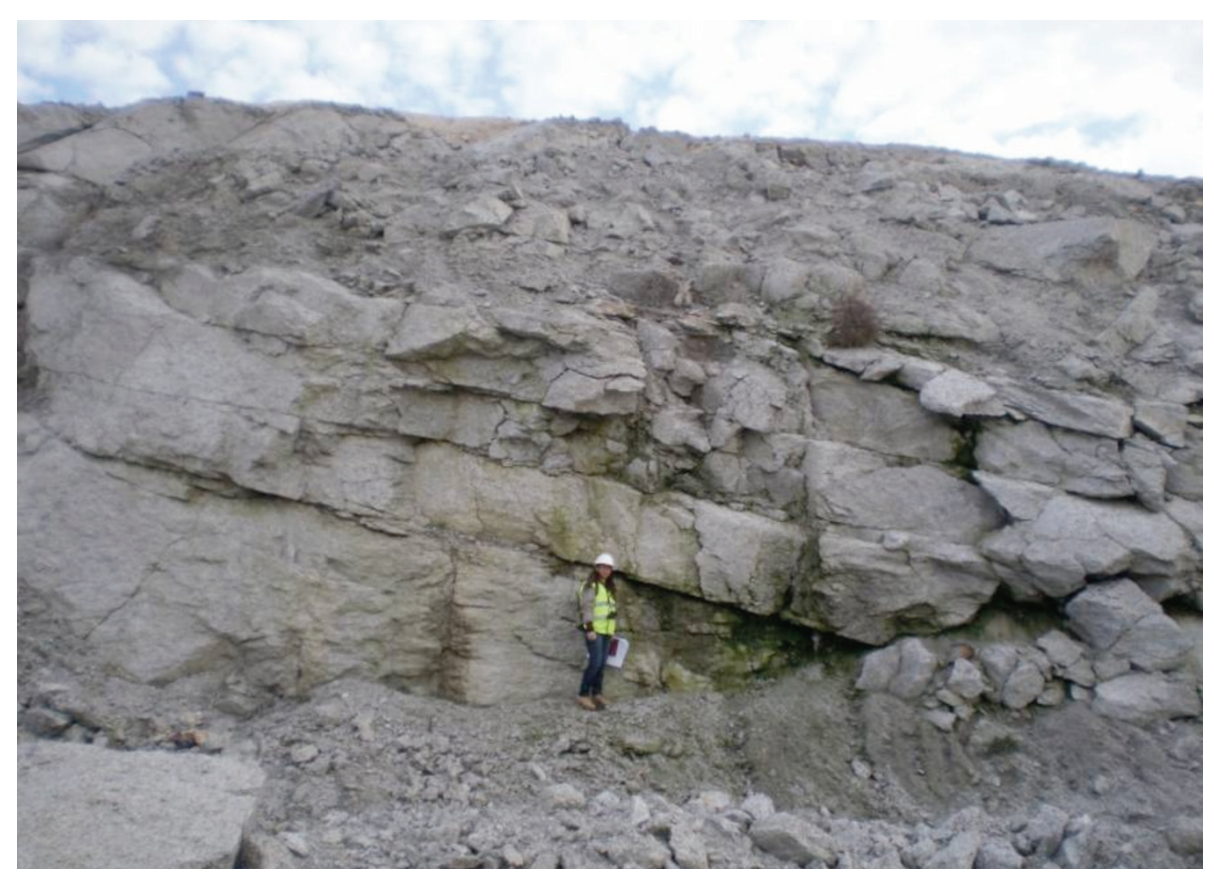

Şekil 2. Foliasyon düzlemleri ve bunlara dik olarak gelişmiş tektonik kökenli eklemler.

Figure 2. Foliation planes and tectonically-originated joints developed nearly perpendicular to these planes

Arazi ölçümleri sonucunda foliasyon yüzeyleri ve eklemleri içeren 88 süreksizlik düzleminin kontur diyagramı, eşit alanlı alt yarım küre stereografik projeksiyon tekniği ile Dips V. 6.0 (Rocscience, 2012) bilgisayar programı kullanılarak elde edilmiştir (Şekil 3).

Kutup noktasi konsantrasyonlarından faydalanılarak, hâkim 3 adet foliasyon ve 5 adet çatlak seti belirlenmiştir. Bu süreksizlik setlerinin mühendislik özellikleri, arazide ayrıntılı olarak incelenmiş, ISRM (1978a)'ya göre sınıflandırılması yapılmıştır. Bu sınıflandırma, nümerik analizlerde kullanılan GSI (Jeolojik Dayanım Indeksi), $m_{i}$ (Kaya materyali için Hoek-Brown sabiti) ve D (Örselenme katsayısı) değerlerinin belirlenmesinde etkili bir parametre olarak kullanılmıştır (Tablo 2). 
Araştırma Makalesi / Research Article



Şekil 3. Eşit alanlı kutupsal stereonet üzerinde eklem ve foliasyon düzlemlerinin konumlarını temsil eden kontur diyagramı.

Figure 3. Contour diagram representing the orientation of joints and foliation planes plotted on a polar equal-area net.

Çizelge 2.İnceleme hatlarından elde edilen süreksizliklerin jeoteknik özellikleri.

Table 2. Geotechnical properties of the discontinuities obtained from the scan-lines.

\begin{tabular}{|c|c|c|c|c|}
\hline \multirow{3}{*}{$\begin{array}{l}\text { Kütle Özellikleri } \\
\text { Süreksizliklerin genel } \\
\text { yönelimleri }\end{array}$} & \multirow{2}{*}{$\begin{array}{l}\text { Foliasyonlar } \\
\left(\mathrm{F}_{1}, \mathrm{~F}_{2} \text { ve } \mathrm{F}_{3}\right)\end{array}$} & \multicolumn{3}{|c|}{ Çatlak setleri } \\
\hline & & $\left(\mathrm{J}_{1}\right)$ ve $\left(\mathrm{J}_{4}\right)$ & $\left(\mathrm{J}_{2}\right)$ & $\left(\mathrm{J}_{3}\right)$ \\
\hline & $\begin{array}{l}\mathrm{F}_{1}: 300 / 32-40 \\
\mathrm{~F}_{2}: 273 / 32-40 \\
\mathrm{~F}_{3}: 243 / 32-40\end{array}$ & $\begin{array}{l}325-340 / 80-87 \\
290-320 / 80-90\end{array}$ & $190 / 70-85$ & $250 / 80-90$ \\
\hline $\begin{array}{l}\text { Süreksizlik aralığ } 1 \\
(\mathrm{~cm})\end{array}$ & $\begin{array}{c}\text { Minimum: } 5 \\
\text { Maksimum: } 25 \\
\text { Ortalama:20 } \\
\text { SD: } 10 \text { (Orta } \\
\text { derecede aralıklı) }\end{array}$ & $\begin{array}{l}\text { Minimum: } 20 \\
\text { Maksimum: } 55 \\
\text { Ortalama: } 35 \\
\text { SD: } 11 \text { (Geniş } \\
\text { aralıklı) }\end{array}$ & $\begin{array}{l}\text { Minimum: } 15 \\
\text { Maksimum:25 } \\
\text { Ortalama:18 } \\
\text { SD: } 07 \text { (Orta } \\
\text { derecede aralıkl1) }\end{array}$ & $\begin{array}{c}\text { Minimum: } 62 \\
\text { Maksimum: } 78 \\
\text { Ortalama:72 } \\
\text { SD: } 2.6 \\
\text { (Çok geniş aralıklı) }\end{array}$ \\
\hline $\begin{array}{l}\text { Süreksizlik } \\
\text { devamlılığ1 }\end{array}$ & $\begin{array}{c}4 \mathrm{~m}-12 \mathrm{~m} \\
\text { (Genellikle yüksek } \\
\text { devamll11k) }\end{array}$ & $\begin{array}{c}1.0 \mathrm{~m}-4.5 \mathrm{~m} \\
\text { (Genellikle düşük } \\
\text { devaml1l1k) }\end{array}$ & $\begin{array}{c}1.0 \mathrm{~m}-2.0 \mathrm{~m} \\
\text { (Düşük devamlılık) }\end{array}$ & $\begin{array}{c}3.0 \mathrm{~m}-8.5 \mathrm{~m} \\
\text { (Orta derecede devaml111k) }\end{array}$ \\
\hline Süreksizlik açıklı̆̆ & $\begin{array}{c}1 \mathrm{~mm}-0.5 \mathrm{~cm}(\text { Orta } \\
\text { derecede geniş) }\end{array}$ & $\begin{array}{c}0.5-2.0 \mathrm{~cm} \\
\left(\begin{array}{c}\text { Genellikle çok } \\
\text { geniş) }\end{array}\right.\end{array}$ & $\begin{array}{l}1 \mathrm{~mm}-1.0 \mathrm{~cm} \\
\text { (Orta derecede } \\
\text { geniş) }\end{array}$ & $\begin{array}{l}0.5 \mathrm{~cm}-3 \mathrm{~cm} \\
\text { (çok geniş) }\end{array}$ \\
\hline $\begin{array}{l}\text { Süreksizlik yüzeyinin } \\
\text { pürüzlülüğü }\end{array}$ & \multicolumn{4}{|c|}{ Genellikle pürüzsüz veya az dalgalı (geniş dalga boyu- az genlik) } \\
\hline Dolgu Malzemesi & \multicolumn{4}{|c|}{ İnce, yumuşak ve nemli dolgu materyali } \\
\hline $\begin{array}{l}\text { Süreksizlik } \\
\text { yüzeyindeki su } \\
\text { durumu }\end{array}$ & \multicolumn{4}{|c|}{ Süreksizlik yüzeyinde damla halinde sızıntı var ancak sürekli bir akış gözlenmiyor } \\
\hline Blok boyutu & \multicolumn{4}{|c|}{ Genellikle orta büyüklükte, bloklu } \\
\hline Bozunma durumu & \multicolumn{4}{|c|}{ Genellikle orta derecede bozunmuş süreksizlik yüzeyleri } \\
\hline
\end{tabular}


Kadakçı Koca, Koca

Kaya şevlerinde, süreksizlikler, suyun kaya kütlesi içerisinde akışına imkan veren kanal görevi görerek, kaya kütlesine ikincil gözeneklilik kazandırmaktadır. Sonuç olarak, açık makaslama çatlakları ve topoğrafik koşullar su akışını kolaylaştırmaktadır. $\mathrm{Bu}$ görüş doğrultusunda, foliasyon düzlemlerine yaklaşık dik gelişmiş makaslama çatlakları arazide incelenmiş ve bu yüzeylere koşut bitki gelişimleri (yosun oluşumu) gözlenmiştir. Ocak ayında, kuvvetli yağışların ardından, arazide gözlenen su çıkış noktaları, albit ocağının topoğrafik haritası üzerine işaretlenmiştir (Şekil 4). Su tablası konturu bu noktalar dikkate alınarak Şekil 4'teki gibi çizilmiştir. Jeoteknik kesit hatlarının su tablasını kestiği noktalar, duraylılık analizlerinde \% 50 su seviyesi olarak dikkate alınmıştır. Ocakta, su seviyesinin maksimum topoğrafik kota kadar çıkması durumu da \% 100 su seviyesi olarak (500 m kotları) her kesit için şev geometrisine işlenmiştir.

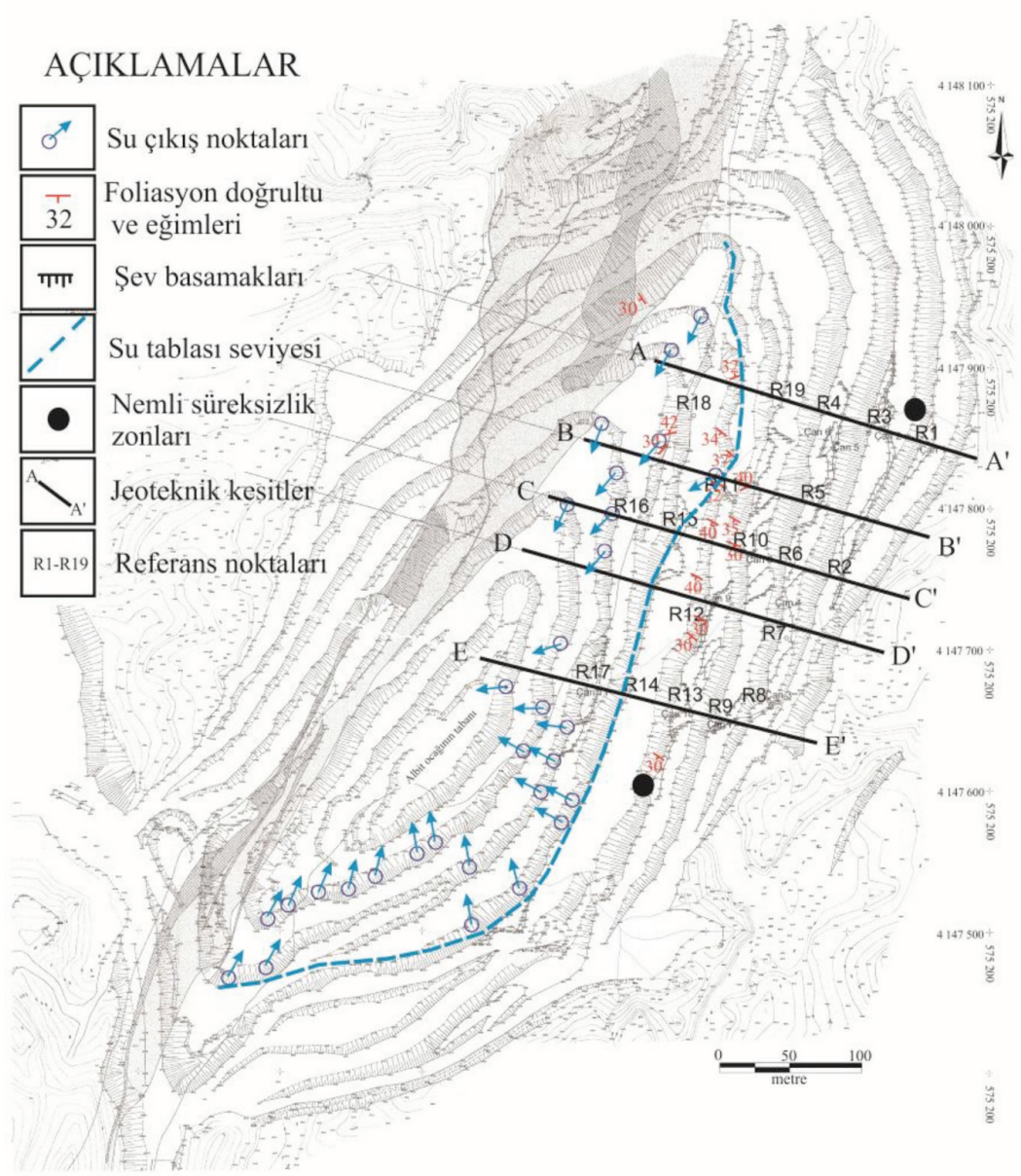

Şekil 4. Alipaşa albit madeninin doğu şevindeki su çıkış noktaları, nemli süreksizlik zonları ve tahmin edilen yeraltısuyu seviyesi.

Figure 4. The location of seeps, wet discontinuity zones and estimated groundwater table level in the eastern part of the Alipaşa albite open pit mine. 


\section{ŞEV DURAYLILIĞI}

Baraj, yol yapımı ve çeşitli mühendislik kazılarında, güvenli ve ekonomik şev tasarımı için, ayrıntılı şev duraylılığg analizleri büyük önem taşımaktadır. Nümerik analizler, yenilmenin gerçekleştiği düzlemin altındaki ve üstündeki gerilme dağılımlarını ve ilerleyici karaktere sahip deformasyonu dikkate aldığı için, günümüzde en çok tercih edilen yöntemlerdendir. Bu çalışmada, albit ocağının şev duraylılık analizleri, iki boyutlu, sonlu elemanlar yöntemini kullanan, Phase $^{2}$ (Rocscience, 2010) adli bilgisayar programı kullanılarak yapılmıştır. Temel olarak, sonlu elemanlar yöntemi (FEM), sürekliliği, nod adı verilen noktalarla (düğüm noktaları) birleşen elemanlar ile tanımlar. Sınırları belirlenmiş, analizlerin gerçekleşeceği ortam, farklı doku seçenekleri ile ağ elemanlarına bölünür. Limit-denge analizlerinin aksine, hesaplar sadece kayma düzleminin üstündeki alan için dilimlere bölünerek değil, tüm modeli kapsayan ağ elemanları içerisinde gerçekleştirilir. $\mathrm{Bu}$ çalışmadaki modeller, 6 adet düğüm noktasına sahip, homojen dağılım gösteren 2000 adet ağ elemanına bölünerek nümerik analizler gerçekleştirilmiştir. Oluşturulan ağ yapısındaki eleman sayısının artırılıp azaltılması analizlerin hassasiyetini etkilemektedir.

Sonlu elemanlar yöntemi, şevin kritik yenilme koşulunu temsil eden gerilme indirgeme faktörü (SRF) veya güvenlik katsayısı değerlerini hesaplayan, makaslama dayanımı indirgeme yöntemini de kullanmaktadır. Sonlu eleman modelinde tanımlanmış bütün materyallerin kesme dirençleri SRF ile indirgenir (Hammah vd., 2005).

FEM analizlerinde öncelikle Genelleştirilmiş Hoek-Brown Yenilme Ölçütü, daha sonra çatlak dokusunu dikkate almayan Eşdeğer Mohr-Coulomb parametrelerini kullanan Mohr-Coulomb Ölçütü kullanılmış, belirli parametrelerin değerlerindeki değişikliğin şev duraylılığ üzerindeki etkileri araştırılmıştır. Örneğin; GSI değerleri 35, 40, 45, şevdeki su tablas1 seviyesi (STS) \%100, \%70, \%50, sismik katsayılar, 0 (sismik ivme yok), $0.1 \mathrm{~g}, 0.2 \mathrm{~g}, 0.3 \mathrm{~g}$, ve şev aç1ları ise $30^{\circ}, 32^{\circ}, 34^{\circ}, 36^{\circ}, 40^{\circ}$ olarak analizlerde girdi olarak kullanılmıştır. KB-GD yönlü kesitlerdeki şev yükseklikleri, AA': 135 m, BB': 123 m, CC': 132 m, DD': 121 m, EE': 101 m'dir (Şekil 4). Her kesitteki şev yükseklikleri sabit olduğundan, söz konusu parametreler (GSI, $\alpha_{\text {sismik }}$, STS) değiştirilerek, farklı şev açılarında duraylılık incelemeleri yapılmıştır.

Ortognayslar üzerinde ISRM (1981) dikkate alınarak birim hacim ağırlık tayini ve ISRM (1978b) standardına göre 3 tanesi deformasyon kontrollü olmak üzere toplam 12 adet tek eksenli sıkışma dayanımı deneyi yapılmış ve sonuçları Tablo 3 'te verilmiştir.

Tablo 3'teki tek eksenli sıkışma değerleri dikkate alınarak, ortognaysların Anon (1977) sınıflandırmasına göre orta dayanımlı kayaçlar olduğu söylenebilir.

Çizelge 3.Ortognaysların nümerik analizlerde kullanılan fiziko-mekanik özellikleri.

Table 3. The physico-mechanical properties of the orthogneisses used in the numerical analyses.

\begin{tabular}{cc}
\hline $\begin{array}{c}\text { Bulunan fiziko-mekanik } \\
\text { parametreler (n: test number) }\end{array}$ & $\begin{array}{c}\text { Deney } \\
\text { Sonuçları }\end{array}$ \\
\hline$\gamma_{\mathrm{n}}\left(\mathrm{kN} / \mathrm{m}^{3}\right) \mathrm{n}: 18$ & $25.9 \pm 0.01$ \\
$\sigma_{\mathrm{ci}}(\mathrm{MPa}) \mathrm{n}: 12$ & $27.34 \pm 5.30$ \\
$\mathrm{E}_{\mathrm{i}}(\mathrm{MPa}) \mathrm{n}: 3$ & $33500 \pm 3.04$ \\
\hline
\end{tabular}




\section{Genelleştirilmiş Hoek-Brown Ölçütü ile Şev Duraylılığı Analizi}

Laboratuvar deneylerinden elde edilen kaya materyalinin dayanım parametreleri, tabaka, foliasyon, çatlak ve faylar gibi süreksizlikler içeren kaya kütlesinin dayanımını tam olarak yansitamamaktadır. Bu süreksizlikler, yenilme düzlemleri olduğundan, kaya kütlesi dayanımını azaltmaktadır. Kaya kütlesi dayanımını, kaya materyali özelliklerinden en doğru yaklaşımla tahmin edebilmek için Hoek vd. (2002) tarafindan Genelleştirilmiş Hoek-Brown Ölçütü önerilmiştir. Çatlaklı kaya kütleleri için Genelleştirilmiş Hoek-Brown ampirik bağıntısı Eşitlik 3'te verilmiştir:

$\sigma_{1}^{\prime}=\sigma_{3}{ }^{\prime}+\sigma_{\mathrm{ci}}\left[\mathrm{m}_{\mathrm{b}}\left(\sigma_{3} / \sigma_{\mathrm{ci}}\right)+\mathrm{s}\right]^{\mathrm{a}}$

$\mathrm{Bu}$ denklemde, $\sigma_{1}$ 've $\sigma_{3}$, yenilme anındaki maksimum ve minimum asal gerilmeler; $m_{i}$ ve $\mathrm{s}$ kaya materyaline, $\mathrm{m}_{\mathrm{b}}$ ise kaya kütlesine ait Hoek-Brown sabitleri; $\sigma_{c i}$ kaya materyalinin tek eksenli sıkışma dayanımı, a ise kaya kütle özelliklerine dayanan üssel bir ifadedir. HoekBrown sabitleri, GSI ve D değeri kullanılarak aşağıdaki eşitliklerden elde edilebilir:

$$
\begin{aligned}
& \mathrm{m}_{\mathrm{b}} / \mathrm{m}_{\mathrm{i}}=\exp ((\text { GSI-100) } /(28-14 \mathrm{D})) \\
& \mathrm{s}=\exp ((\mathrm{GSI}-100) /(9-3 \mathrm{D})) \\
& \mathrm{a}=1 / 2+1 / 6\left(\mathrm{e}^{-\mathrm{GSI} / 15}-\mathrm{e}^{-20 / 3}\right)
\end{aligned}
$$

GSI parametresi, blok boyutu ve yüzey koşulları gibi süreksizlik özelliklerinin kaya kütlesi dayanımındaki azaltıcı etkisini dikkate alarak Marinos ve Hoek (2001) tarafindan oluşturulan tablolardan belirlenebilen, arazi verilerine dayanan bir değerdir. GSI değeri 10 (çok zayıf kaya) ve 100 (sağlam kaya) arasında değişir. D ise patlatma şeklinin kaya kütlesi üzerinde oluşturduğu deformasyon dikkate alınarak Hoek (2006)'da verilen tablodan faydalanılarak belirlenebilir. D değeri 0 ile 1 arasında değişmekte olup, sırasıyla örselenmemiş kaya kütlesi ve çok örselenmiş kaya kütlesini temsil etmektedir. Kaya materyalini tanımlayan $m_{i}, 4$ ile 33 arasında değer alır ve tablodan (Hoek, 2006) veya kaya materyali üzerinde yapılan üç eksenli sıkışma dayanımında uygulanan asal gerilmelerden faydalanılarak bulunabilir. Genelleştirilmiş Hoek-Brown Ölçütü ile FEM kullanılarak yapılan analizler için gerekli diğer parametreler Tablo 4’te verilmiştir.

Çizelge 4.Genelleştirilmiş Hoek-Brown Ölçütü dikkate alınarak yapılan nümerik analizlerde kullanılan kaya materyali ve kaya kütle özellikleri.

Table 4. Rock material and rock mass properties used in the numerical analyses considering the Generalized Hoek-Brown Criterion.

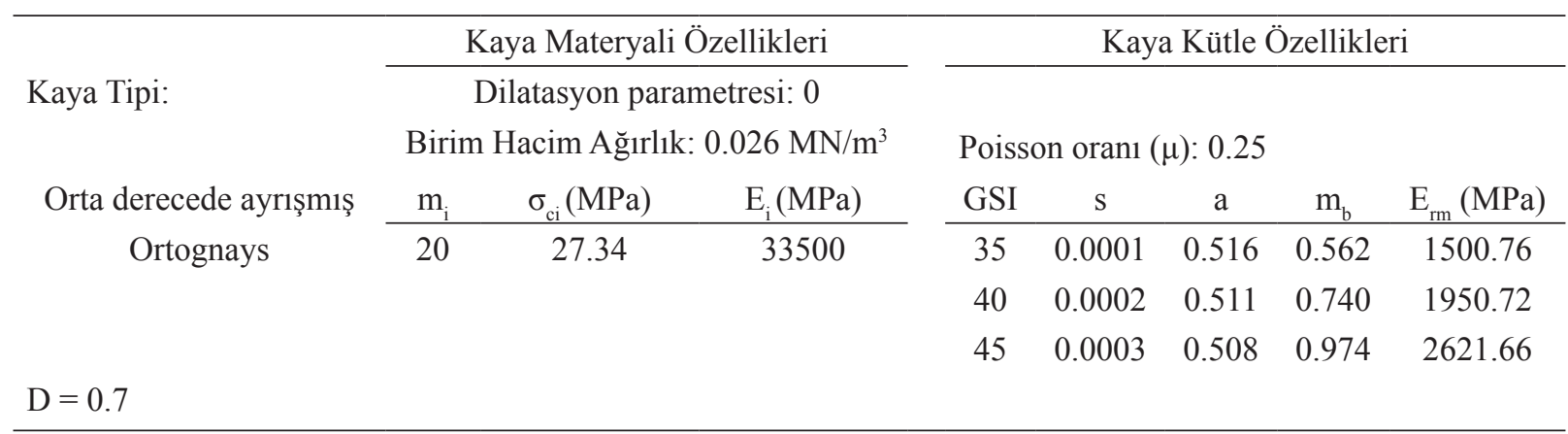



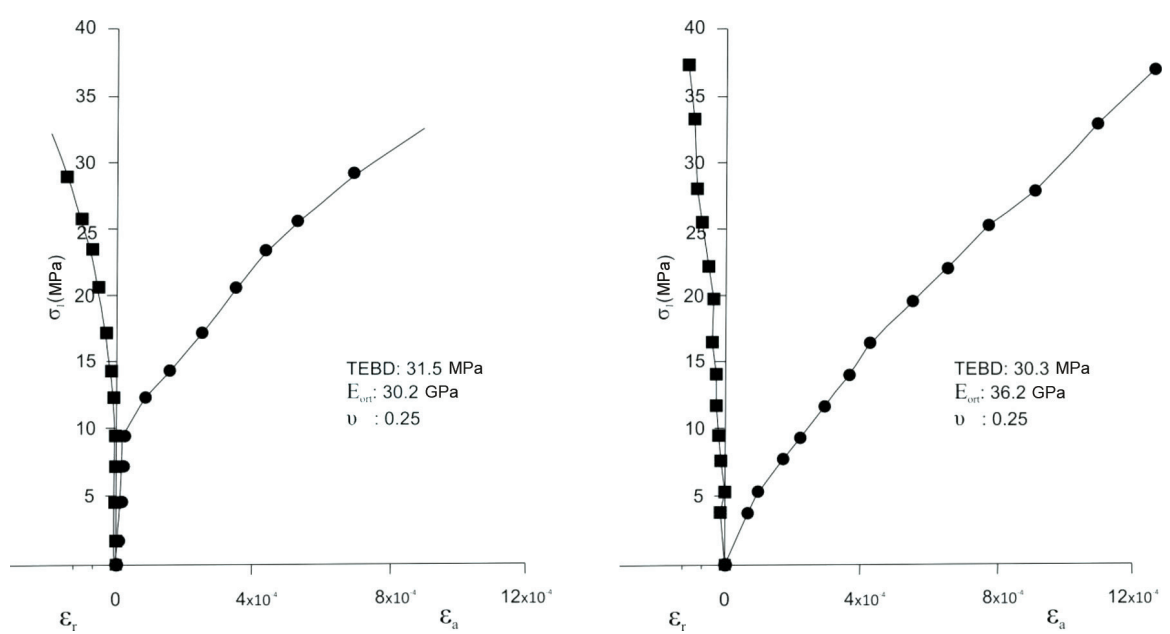

Şekil 5. Ortognays karot örneği üzerinde yapılan deformasyon kontrollü tek eksenli sıkışma dayanımı deneyinden elde edilen gerilme-deformasyon eğrisi.

Figure 5. The stress-strain curve obtained from the strain controlled uniaxial compressive strength test conducted on the core sample of the orthogneisses.

Kaya materyali üzerinde yapılan tek eksenli sıkışma dayanımı deneyi ile $\sigma_{\text {ci }}$ belirlenmiştir. Deformasyon kontrollü tek eksenli sıkışma deneyinden elde edilen gerilme-deformasyon eğrisi (Şekil 5) dikkate alınarak kaya materyaline ait ortalama elastisite modülü $\left(\mathrm{E}_{\mathrm{i}}\right)$ belirlenmiştir (Koca vd., 2010).

$\mathrm{E}_{\mathrm{rm}}$ (kaya kütlesinin elastisite modülü) ise RocLab V.0.1 (Rocscience, 2007) bilgisayar programinda Hoek ve Diederichs (2006)'ya ait eşitlik dikkate alınarak hesaplanmıştır. Bu eşitlik, $\mathrm{E}_{\mathrm{i}}$, D ve GSI değerlerine dayanmaktadır: $\mathrm{E}_{\mathrm{rm}}=\mathrm{E}_{\mathrm{i}}\left(0.02+(1-(\mathrm{D} / 2)) / 1+\mathrm{e}^{(60+15 \mathrm{D}-\mathrm{GSI} / 11)}\right.$ (GPa)

Materyal özellikleri dişında, programa piyezometrik ve sismik özellikler de girildiğinde her bir durum için SRF değerleri hesaplanmıştır. 5 adet jeoteknik kesit için, farklı koşullar (5 adet şev açısı, 4 adet sismik katsayı değeri, 3 adet GSI değeri, 3 adet piyezometrik durum) uygulandığında oluşan kombinasyon sayısı kadar
SRF değeri elde edilmiştir. SRF değerlerinin her bir koşuldaki değişimi grafiksel olarak Şekil 6'da verilmektedir.

900 adet SRF değerinin hangi değișken ile yüksek korelasyona sahip olduğunu belirlemek amaciyla da SPSS V.15.0.1 (2006) programı kullanılarak çok değişkenli analiz yapılmıştır. $\mathrm{Bu}$ analiz sonucunda, SRF değeri üzerinde en etkili parametrenin şev açısı olduğu, daha sonra sırasıyla, GSI, şevdeki su tablası seviyesi (STS $\%$ ), sismik katsayı ve şev yüksekliğinin geldiği belirlenmiştir. Bağımlı değişken olarak SRF değerinin bağımsız değişkenlerle olan doğrusal regresyon analizleri sonucunda ise, korelasyon katsayısı 0.696 olan doğrusal bir eşitlik elde edilmiştir.

$\mathrm{SRF}=2.060-0.399 \alpha_{\text {sismik }}-0.039 \alpha_{\text {şev }}+0.017 \mathrm{GSI}-$ 0.002 STS- $0.002 \mathrm{H}_{\text {şev }}$ r: 0.696

$\left(\alpha_{\text {sismik }}:\right.$ sismik katsayı; $\alpha_{\text {sev }}:$ şevaçııı; GSI: Jeolojik Dayanım Indeksi; STS: su tablası seviyesi; $H_{\text {şev }}$ : şev yüksekliği) 
Kadakçı Koca, Koca

Su Tablası Seviyesi:100\% (Genelleştirilmiş Hoek-Brown)
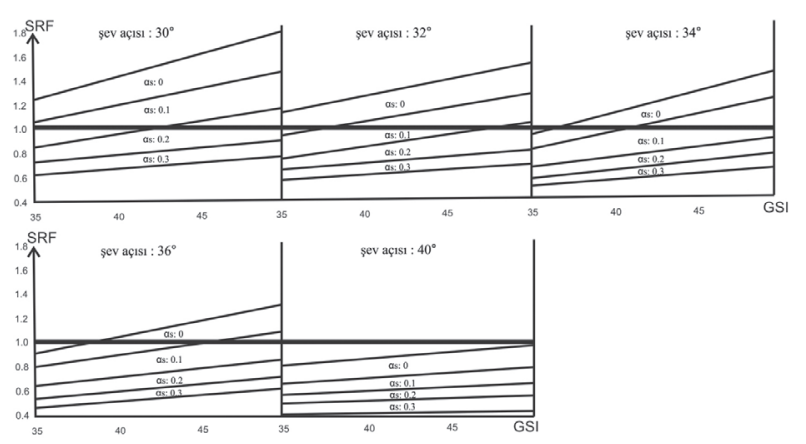

Su Tablası Seviyesi: 50\% (Genelleştirilmiş Hoek-Brown)
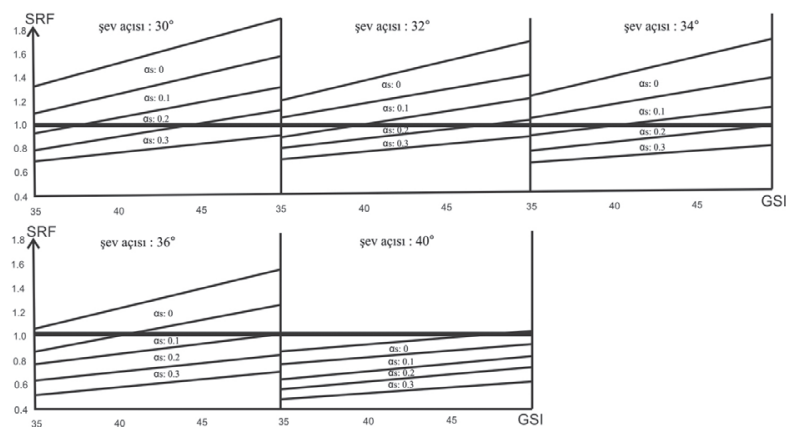

Su Tablası Seviyesi: 70\% (Genelleştirilmiş Hoek-Brown)

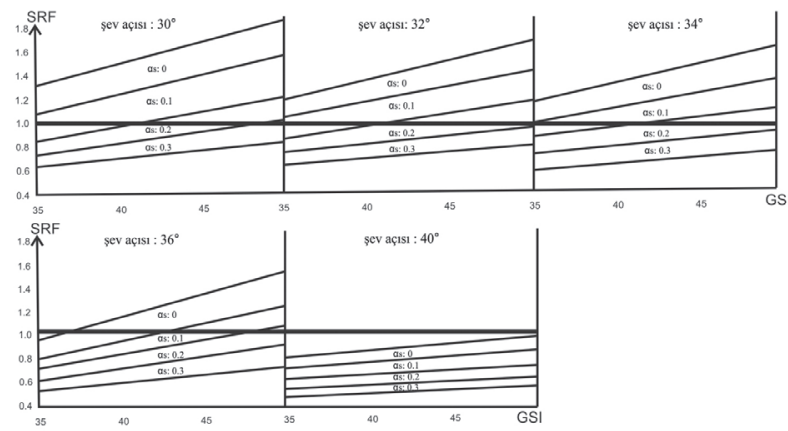

Şekil 6. Genelleştirilmiş Hoek-Brown Ölçütü’nü dikkate alan, farklı su tablası seviyeleri için, GSI değerleri ile SRF değerleri arasındaki ilişkiyi gösteren grafikler.

Figure 6. The graphs showing the relationship between GSI and SRF values under the conditions of various water table levels considering the Generalized Hoek-Brown Criterion.

\section{Eşdeğer Mohr-Coulomb Parametreleri ile Şev Duraylılığı Analizleri}

Hoek vd. (2002) tarafından, Eşdeğer MohrCoulomb parametreleri, belirli bir gerilme aralığında, doğrusal Mohr-Coulomb ile doğrusal olmayan Hoek-Brown eğrilerinin arasındaki alanların en aza indirgenmesiyle bulunan c ve $\phi$ değerleri olarak tanımlanmıştır. Başka bir deyişle, Mohr-Coulomb eğrisinin geometrik olarak pozitif alanlarının (Mohr-Coulomb doğrusunun üzerindeki alan) toplamı, negatif alanlarının
(Mohr-Coulomb doğrusunun altındaki alan) toplamına eşitlenmeye çalışılır (Şekil 7).

$\mathrm{Bu}$ çalışmadaki modellerde, süreksizlik özellikleri şev modeline girilmeden, Hoek vd. (2002) tarafından önerilen eşitliklerle bulunan Eşdeğer Mohr-Coulomb parametreleri kullanılarak duraylılık çalışmaları yürütülmüştür.

İki yenilme zarfının birbirlerine uyum işlemi, şevdeki çekme dayanımından maksimum sıkışma dayanımına kadar olan gerilme aralığında yapılmaktadır. Hoek (2006) tarafından Eşdeğer 


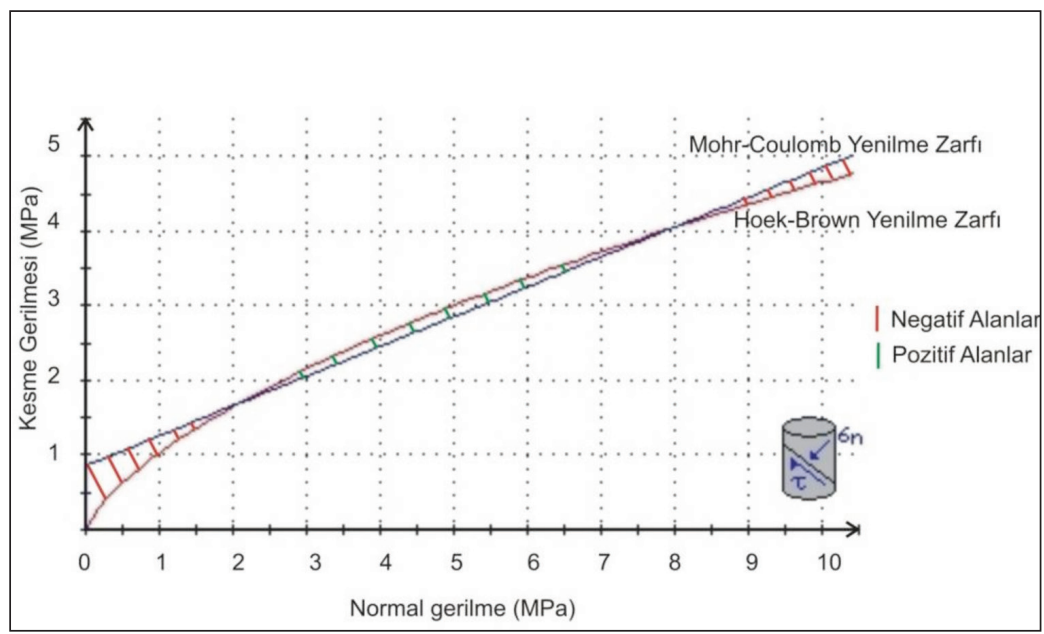

Şekil 7. Doğrusal Mohr-Coulomb ve doğrusal olmayan Hoek-Brown Yenilme zarflarının arasındaki negatif ve pozitif alanların grafiksel gösterimi.

Figure 7. The graphical definition of the positive and negative areas between linear Mohr-Coulomb and non-linear Hoek-Brown failure envelopes.

Mohr-Coulomb parametrelerinin hesaplanmas1 Eşitlik 9 ve 10'da verilmiştir:

$\phi^{\prime}=\sin ^{-1}\left[\left(6 a m_{b}\left(s+m_{b} \sigma_{3 n}\right)^{a-1}\right) /(2(1+a)(2+a)+\right.$ $\left.\left.6 a m_{b}\left(s+m_{b} \sigma_{3 n}\right)^{a-1}\right)\right]$

$c^{\prime}=\left[\sigma_{c i}\left[(1+2 a) s+(1-a) m_{b} \sigma_{3 n}\right)\right]\left(s+m_{b} \sigma_{3 n}\right)$

$\left.{ }^{a-1}\right] /\left[(1+a)(2-a)+\left[1+6 a m_{b}\left(s+m_{b} \sigma^{\prime}{ }_{3 n}\right)^{a-1} /(1+a)\right.\right.$ $\left.(2+a)]^{0.5}\right]$

Formüllerdeki $\sigma_{3 \mathrm{n}}^{\prime}$; materyalin maksimum sıkışma dayanımının, tek eksenli sıkışma dayanımına oranıdır. Maksimum sıkışma dayanımı Hoek-Brown ve Mohr-Coulomb yenilme zarflarının aralarındaki ilişkinin irdelendiği üst sınırdır ve Eşitlik 11'de verilmektedir:

$$
\sigma_{3 \max }^{\prime}=0.72 \sigma_{\mathrm{cm}}^{\prime}\left(\sigma^{\prime}{ }_{\mathrm{cm}} / \mathrm{\gamma H}\right)^{-0.91}
$$

Burada, $\gamma$, kaya kütlesinin birim hacim ağırlı̆̆ı; H, şev yüksekliği; $\sigma^{\prime}{ }_{\mathrm{cm}}$, ise global kaya kütle dayanımıdır ve Eşitlik 12 ile hesaplanır:

$$
\sigma^{\prime}{ }_{\mathrm{cm}}=\sigma_{\mathrm{ci}}\left[\mathrm{m}_{\mathrm{b}}+4 \mathrm{~s}-\mathrm{a}\left(\mathrm{m}_{\mathrm{b}}-8 \mathrm{~s}\right)\left(\mathrm{m}_{\mathrm{b}} / 4+\mathrm{s}\right)^{\mathrm{a}-1} / 2\right.
$$

$(1+a)(2+a)]$
Eşdeğer Mohr-Coulomb parametreleri, Phase $^{2}$ programı içerisindeki, RocLab V.0.1 (Rocscience, 2007) programı ile hesaplanmış ve Tablo 5'te sonuçları verilmiştir.

Nümerik hesaplamalar sonucunda elde edilen 900 adet SRF değerinin bağımlı olduğu parametrelere göre değişimi grafiksel olarak Şekil 8'de verilmiştir. Daha sonra, SRF değerleri üzerinde çok değişkenli analiz yapılmıştır. SRF değeri üzerinde en etkili parametrenin şev açısı olduğu daha sonra ise sırasıyla, su tablası seviyesi (STS \%), GSI, sismik katsayı ve şev yüksekliğinin geldiği belirlenmiştir. Doğrusal regresyon analizleri sonucunda ise, korelasyon katsayısı 0.680 olan doğrusal bir eşitlik elde edilmiştir.

$$
\begin{aligned}
& \mathrm{SRF}=3.037-0.593 \alpha_{\text {sismik }}-0.060 \alpha_{\text {sev }}+0.021 \mathrm{GSI} \\
& -0.006 \mathrm{STS}-0.003 \mathrm{H}_{\text {şev }} \text { r: } 0.680
\end{aligned}
$$




\section{Kadakçı Koca, Koca}

Çizelge 5. Farklı GSI değerleri ve her bir kesite ait şev yüksekliği için nümerik analizlerde kullanılan eşdeğer Mohr-Coulomb parametreleri.

Table 5. The Equivalent Mohr-Coulomb parameters used in the numerical analyses for various GSI values and the slope heights of each cross-section.

Ortognays Kaya Kütle Özellikleri

GSI

$40 \quad 45$

\begin{tabular}{|c|c|c|c|c|c|c|c|c|c|c|c|c|c|}
\hline $\begin{array}{l}\text { Kesit } \\
\text { Hatları }\end{array}$ & $\begin{array}{c}\text { Şev } \\
\text { Yüksekliği } \\
\text { (m) }\end{array}$ & $\begin{array}{c}\mathrm{c} \\
(\mathrm{MPa})\end{array}$ & $\Phi\left(^{\circ}\right)$ & $\begin{array}{c}\sigma_{\mathrm{t}} \\
(\mathrm{MPa})\end{array}$ & $\begin{array}{c}E_{\mathrm{rm}} \\
(\mathrm{MPa})\end{array}$ & $\begin{array}{c}\mathrm{c} \\
(\mathrm{MPa})\end{array}$ & $\Phi\left({ }^{\circ}\right)$ & $\begin{array}{c}\sigma_{\mathrm{t}} \\
(\mathrm{MPa})\end{array}$ & $\begin{array}{c}\mathrm{E}_{\mathrm{rm}} \\
(\mathrm{MPa})\end{array}$ & $\begin{array}{c}\mathrm{c} \\
(\mathrm{MPa})\end{array}$ & $\Phi\left({ }^{\circ}\right)$ & $\begin{array}{c}\sigma_{\mathrm{t}} \\
(\mathrm{MPa})\end{array}$ & $\mathrm{E}_{\mathrm{rm}}(\mathrm{MPa})$ \\
\hline A-A' & 135 & 0.436 & 29.46 & & & 0.497 & 31.83 & & & 0.562 & 34.17 & & \\
\hline B-B' & 123 & 0.412 & 30.14 & & & 0.470 & 32.53 & & & 0.531 & 34.87 & & \\
\hline C-C' & 132 & 0.430 & 29.62 & 0.004 & 1500.76 & 0.491 & 32 & 0.006 & 1950.72 & 0.526 & 35 & 0.010 & 2621.66 \\
\hline D-D' & 121 & 0.408 & 30.26 & & & 0.465 & 32.65 & & & 0.554 & 34.34 & & \\
\hline E-E' & 101 & 0.365 & 31.58 & & & 0.416 & 34.01 & & & 0.471 & 36.38 & & \\
\hline
\end{tabular}

Dilatasyon Açısı $(\psi)$ : 0

Su Tablası Seviyesi:100\% (Eşdeğer Mohr-Coulomb)
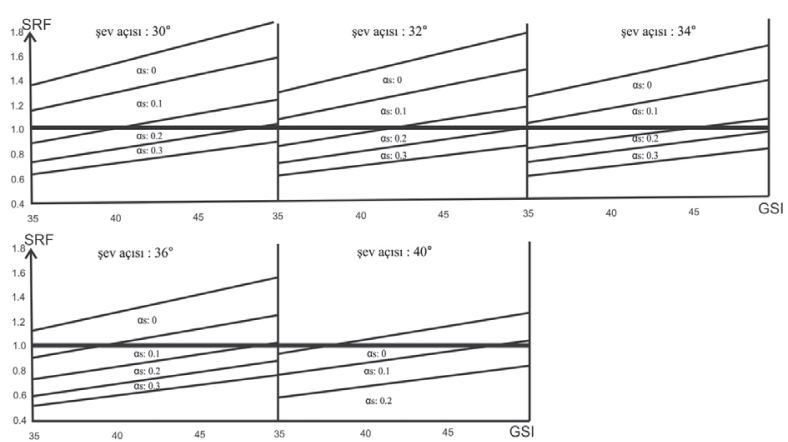

Su Tablası Seviyesi: 50\% (Eşdeğer Mohr-Coulomb)
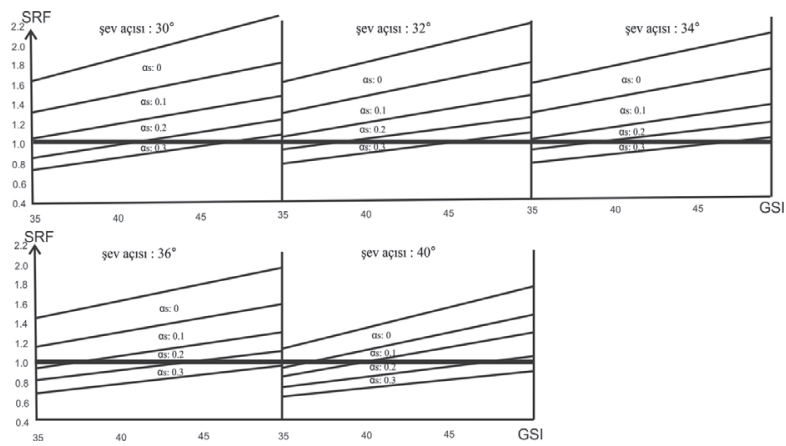

Şekil 8. Eşdeğer Mohr Coulomb Parametrelerini dikkate alan GSI değerleri ile SRF değerleri arasındaki ilişkiyi farklı su tablası seviyeleri için gösteren grafikler.

Figure 8. The graphs showing the relationship between GSI and SRF values under the conditions of various water table levels considering the Equivalent Mohr-Coulomb Parameters.
Su Tablası Seviyesi: 70\% (Eşdeğer Mohr-Coulomb)
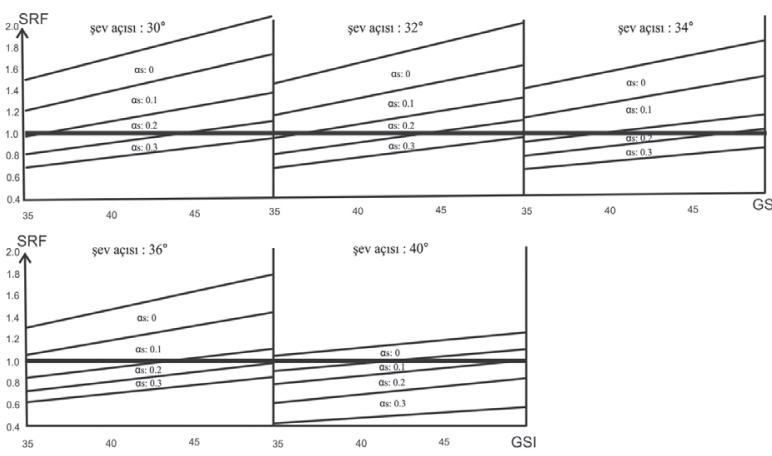


\section{TARTIŞMA VE SONUÇLAR}

Albit açık ocak işletmesinin doğu yamacında yeralan ortognaysların şev duraylılı̆̆ değerlendirmesi için, iki boyutlu sonlu elemanlar yöntemine dayanan Phase $^{2}$ programı, Genelleştirilmiş Hoek-Brown Ölçütü ve eşdeğer Mohr-Coulomb parametreleri dikkate alınarak kullanılmıştır. Kayma türü ve nihai şev açısı tahmin edilmiş, her iki yöntemin uygulanabilirliği incelenmiş, değişken parametrelerin şev duraylılığ1 üzerindeki etkisi istatiksel olarak belirlenmiştir. Şevleri oluşturan basamaklarda $\left(\alpha_{\text {şevbasamak }}=40-60^{\circ}\right)$, eğim açıları $32^{\circ}-40^{\circ}$ arasında değişen foliasyon düzlemleri düzlemsel kayma oluştururken, $\alpha_{\text {şev }}<\alpha_{\text {foliasyon }}$ durumu oluştuğu için genel şevde oluşturmamaktadır. Bir diğer ifade ile, foliasyon düzlemleri ya genel şeve paralel konumda ya da yamaç tabanına doğru yönelmektedir. Analizlerde belirlenen kayma yüzeyi, tansiyon çatlaklarından başlayarak, rotasyonel bir özellik ile şev topuğuna kadar devam etmektedir (Şekil 9).

Basamaklardaki yenilme, foliasyon ve basamak yönelimlerinin ilişkisi değerlendirildiğinde düzlemsel iken, tüm şevde rotasyonel bir kayma düzlemi belirlenmiştir. Şev modeline, süreksizlikler ve bu süreksizliklerin bazı jeoteknik özellikleri (açıklık, aralık, devamlılık gibi) girilmemiştir; bunun yerine, aynı özellikleri karşılayan GSI, $m_{i}$ ve D değerleri ile kaya kütle parametreleri tanımlanmıştır. $\mathrm{Bu}$ nedenle program, düşük-orta dayanımlı olan ortagnays kaya kütlesini relatif olarak çok çatlaklı kaya kütlesi sınıfında değerlendirerek dairesel bir kayma yüzeyi oluşturmuştur.

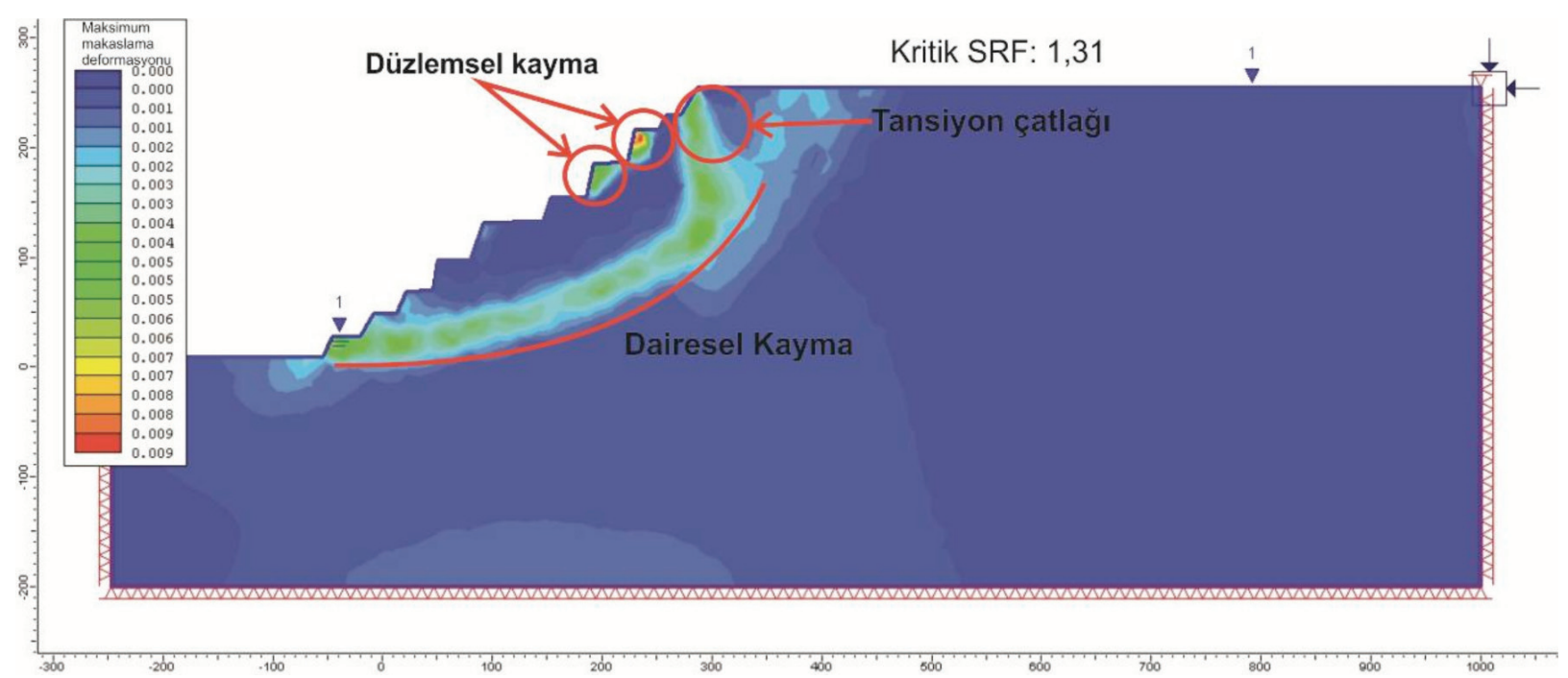

Şekil 9. Kayma türünü gösteren program çıktısı (GSI:40, şev açısı: 36², depremsiz koşul, 100\% doygun, B-B' kesiti, MohrCoulomb Ölçütü).

Figure 9. The output of the failure mode (GSI:40, slope angle: $36^{\circ}$, non seismic, $100^{\circ}$ saturated, B-B' cross section, MohrCoulomb Criterion). 
Kadakçı Koca, Koca

Şev açısının duraylılık üzerindeki en etkili parametre olduğu, bunu takiben sirasıyla, suya doygunluk, GSI, sismik katsayı ve şev yüksekliğinin geldiği belirlenmiştir.

Şekil 6'da ve şekil 8'de grafiksel olarak açıklandığı gibi, $36^{\circ}$ ve $40^{\circ}$ şev açılarında, sismik koşulların bulunmadığg durumda bile yenilme meydana gelmektedir. Bunun yanı sıra, suya doygunluğun \% 70, sismik katsayının $0.1 \mathrm{~g}$, GSI değerinin ise 42 olduğu öngörüldüğünde, oluşturulan grafiklerden, nihai şev açısının $32^{\circ}$ olması gerektiği belirlenmiştir.

Her iki yöntemden elde edilen, normal dağılım gösteren SRF değerlerini karşılaştırmak amacıyla yapılan "bağımlı iki örneklem $\mathrm{T}$ testi" sonucunda, iki grubun ortalamaları karşılaştırılarak, aradaki farkın rastlantısal olarak mı yoksa istatistiksel olarak mı anlamlı olduğu belirlenmiştir. t testi, nümerik analizlerde kullanılan 5 farklı şev açısı için, Genelleştirilmiş Hoek-Brown ve Eşdeğer Mohr-Coulomb parametreleri arasındaki ilişkiyi belirlemek amacıyla uygulanmıştır. \% 95 güven düzeyinde, bağımlı örneklem ortalamaları arasında anlamlı bir fark $(\mathrm{p}<.05)$ olduğu saptanmıştır. Her bir şev açısı için, iki yönteme ait ortalama SRF değerleri arasındaki korelasyon katsayıları Tablo 6'da verilmiştir. Buna göre, iki yöntem arasındaki ilişkinin göreceli olarak şev açısı arttıkça azaldığı görülmektedir.

Mohr-Columb Ölçütü'nün $40^{\circ}$ lik şev açısında çok düşük SRF değerleri vermesinin, yerel kaymayı tetikleyebilecek şev geometrisine bağl1 olduğu düşünülmüştür. Sonuç olarak eşdeğer Mohr-Coulomb parametreleri kullanılarak yapılan analizlerde $40^{\circ}$ 'den düșük açılarda Genelleştirilmiş Hoek-Brown Ölçütü’ne göre ortalama 0.14 kadar daha yüksek SRF değerleri elde edilirken, $40^{\circ}$ den dik şevler için çok daha düşük SRF değerleri elde edilmiştir. Bu da, eşdeğer parametreler kullanılarak uygulanan Mohr-Coulomb Ölçütü'nün çok çatlaklı kaya kütlelerinde $40^{\circ}$, den dik şevler için tercih edilmemesi gerektiğini göstermektedir.

Çizelge 6. Genelleştirilmiş Hoek-Brown ve Eşdeğer Mohr-Coulomb parametreleri ile elde edilen SRF değerlerinin ortalamaları arasındaki korelasyon katsayılarını gösteren, 5 farklı şev açısı için bağımlı iki örneklem T testi çıktısı.

Table 6. The T test output of the paired samples for 5 different slope angles showing correlation coefficients of the mean SRF values obtained from Generalized Hoek-Brown and Equivalent Mohr-Coulomb parameters.

\begin{tabular}{cccc}
\hline & \multicolumn{2}{c}{ Bağımlı İki Örneklem Korelasyonları } & Sig. \\
\hline Şev açısı & $\mathrm{N}$ & Korelasyon & 0.000 \\
$30^{\circ}$ & 180 & 0.961 & 0.000 \\
$32^{\circ}$ & 180 & 0.920 & 0.000 \\
$36^{\circ}$ & 180 & 0.931 & 0.000 \\
$40^{\circ}$ & 180 & 0.916 & 0.000 \\
\hline
\end{tabular}

N: Karşılaştırılan veri sayısı

Sig. : p değeri 


\section{KAYNAKLAR}

Anon, 1977. The description of rock masses for engineering purposes. Quarterly Journal of Engineering Geology, 10, 43-52.

Candan, O., Çetinkaplan, M., Oberhansli, R., Rimmele, G., Akal, C., 2005. Alpine highpressure/Low temperature metamorphism of Afyon Zone and implication for metamorphic evolution of western Anatolia, Turkey. Lithos, $84,102-124$.

Dips V 6.0, 2012. Graphical and Statistical Analysis of Orientation Data, Rocscience Inc.

Fukushima, Y., Tanaka, T., 1990. A new attenuation relation for peak horizontal acceleration of strong earthquake ground motion in Japan. Bulletin of the Seismological Society of America, 80, 757-783.

Graciansky, P., 1965. Précisions sur le métamorphisme du massif de Menderes le long de sa bordure meridionale. Bulletin of the Mineral Research and Exploration Institute of Turkey, 64, 9-23.

Hammah, R.E., Yacoub, T.E., Corkum, B., Curran, J.H., 2005. The Shear strength reduction method for the Generalized Hoek-Brown Criterion. In Proceedings of the $40^{\text {th }}$ U.S. Symposium on Rock Mechanics, AlaskaRocks 2005, Anchorage, Alaska.

Hoek, E., 2006. Rock Mass Properties, In Practical Rock Engineering. Canada: The University of Toronto Press, 1-47 p.

Hoek, E., Bray, J.W., 1981. Rock Slope Engineering ( $3^{\text {rd }}$ Edition). Institution of Mining and Metallurgy, London, 309 p.

Hoek, E., Brown, E.T., 1997. Practical estimates of rock mass strength. International Journal of Rock Mechanics and Mining Sciences, 34 (8), 1165-1186.

Hoek, E., Diederichs, M.S., 2006. Empirical estimation of rock mass modulus. International
Journal of Rock Mechanics and Mining Sciences, 43, 203-215.

Hoek, E., Carranza-Torres, C., Corkum, B., 2002. Hoek-Brown criterion-2002 edition. In Proceedings of North American Rock Mechanics Symposium, Toronto, Canada, 1, 267-273.

http:/earthquake.usgs.gov/earthquakes/world/ historical.php/

ISRM, 1978a. Suggested methods for the quantitative description of discontinuities in rock masses. International Journal of Rock Mechanics and Mining Sciences \& Geomechanics Abstracts, 15, 319-368

ISRM, 1978b. uggested methods for determining the uniaxial compressive strength and deformability of rock materials. International Journal of Rock Mechanics and Mining Sciences \& Geomechanics Abstracts, 16, 135-140.

ISRM, 1981. Rock Characterization, Testing and Monitoring: ISRM Suggested Methods. E.T. Brown (ed.), Pergamon Press, 211 p.

Koca, M. Y., Kahraman, B., Karakuş, D., Özdoğan, M. V., 2010. General assessment of the stability of Overall slope of Ali Paşa Albite Mine, D.E.Ü. İZTEK, İzmir, $156 \mathrm{~s}$.

Li, A.J., Merifield, R.S., Lyamin, A.V., 2008. Stability charts for rock slopes based on the Hoek-Brown failure criterion. International Journal of Rock Mechanics and Mining Sciences, 45, 689-700.

Marinos, P., Hoek, E., 2001. Estimating the geotechnical properties of heterogeneous rock masses such as flysch. Bulletin of the Engineering Geology and the Environment, 60, 85-92.

Nekouei, A.M., Ahangari, K., 2013. Validation of Hoek-Brown failure criterion charts for rock slopes. International Journal of Mining Science and Technology, 23 (6), 805-808. 
Kadakçı Koca, Koca

Phase 2 V 7.013, 2010. Two-dimensional finite element analysis program. Rocscience Inc.

RocLab V.0.1, 2007. Rock Mass Strength Analysis using the Generalized Hoek-Brown Failure Criterion. Rocscience Inc.

Sofianos A.I., 2003. Tunnelling Mohr-Coulomb strength parameters for rock masses satisfying the generalized Hoek-Brown failure criterion. International Journal of Rock Mechanics and Mining Sciences, 40, 435-440.

Sofianos, A. I., Halakatevakis, N., 2002. Equivalent tunnelling Mohr-Coulomb strength parameters for given Hoek-Brown ones. International Journal of Rock Mechanics and Mining Sciences, 39, 131-137.

Sofianos, A.I., Nomikos, P.P., 2006. Equivalent MohrCoulomb and generalized Hoek-Brown strength parameters for supported axisymmetric tunnels in plastic or brittle rock. International Journal of
Rock Mechanics and Mining Sciences, 43, 683704.

SPSS V. 15.0.1, 2006. Statistical Package For Social Sciences. IBM.

Şengör, A.M.C., 1987. Cross-faults and differential stretching of hanging walls in regions of lowangle normal faulting: examples from western Turkey. In Coward, M. P.,Dewey, J. F.,Hancock, P. L., (Ed.). Continental Extensional Tectonics, Geological Society (28th ed.), 575-589.

Tanyaş, H., Ulusay, R., 2013. Assessment of structurally-controlled slope failure mechanisms and remedial design considerations at a feldspar open pit mine, Western Turkey. Engineering Geology, 155, 54- 68.

Uygun, A., Gümüşçü, A., 2000. Geology and origin of the albite deposite of the Çine submassif, southern Menderes Massif (SW-Turkey). Bulletin of the Mineral Research and Exploration, 122, 23-30. 